\title{
Tomato Pinworm, Keiferia lycopersicella (Walshingham) ${ }^{1}$
}

\author{
S. L. $\mathrm{Poe}^{2}$
}

\section{Introduction}

The tomato pinworm is a small, microlepidopteran moth that is often confused with closely related species which have similar habits. Apparently, much of the damage to tomatoes attributed to the eggplant leafminer (Gnorimoschema glochinella Zeller) in Mexico and California during the early 1920s was actually inflicted by the tomato pinworm (Morrill 1925). It persisted in the literature as the eggplant leafminer until redescribed as a new species (Busck 1928) collected from tomatoes. It was later synonymized with Eucatoptus lycopersicella Walshingham. Capps (1946) provided a key, with descriptions, that defines the species and permits identification of larvae with which it might be confused.

\section{Distribution}

Tomato pinworms are found in the warm agricultural areas of Mexico, California, Texas, Hawaii, Cuba, Haiti and the Bahamas. Also, they have been reported from greenhouses in Delaware, Mississippi, Missouri, Pennsylvania and Virginia. Fields near greenhouses may become infested, but the species does not overwinter out of doors in colder regions (Thomas 1933). In Florida, it is common in tomato-producing areas south of Tampa along the west coast and from Ft. Pierce south along the east coast.

\section{Life History}

The developmental time for each stage from egg to adult is shown in the table below (Elmore and Howland, 1943). Eggs are laid singly or grouped in two's and three's on the host-plant foliage. The eggs are opaque to pale yellow when laid, but turn orange before hatching. The first instar larvae spin a tent of silk over themselves and tunnel into the leaf. Further feeding results in a blotch-like mine usually on the same leaf. The third and fourth larval stages feed from within tied leaves, folded portions of a leaf, or enter stems or fruits. Mature larvae abandon the host and form a loose pupal cell of sand grains near the soil surface. The adult emerges from this pupal cell two to four weeks later. Although the life cycle is lengthy, generations overlap and infestations quickly mount to damaging proportions. Seven or eight generations or more per year can be expected.

1. This document is EENY-074 (originally published as DPI Entomology Circular No. 131), one of a series of Featured Creatures from the Entomology and Nematology Department, Florida Cooperative Extension Service, Institute of Food and Agricultural Sciences, University of Florida. Published: February 1999. This document is also available on Featured Creatures Website at http://creatures.ifas.ufl.edu. Please visit the EDIS Website at http://edis.ifas.ufl.edu. Additional information on these organisms, including many color photographs, is available at the Entomology and Nematology Department WWW site at http://entnemdept.ifas.ufl.edu/.

2. S. L. Poe, Department of Entomology and Nematology, University of Florida, Gainesville, FL 32611.

The Institute of Food and Agricultural Sciences is an equal opportunity/affirmative action employer authorized to provide research, educational information and other services only to individuals and institutions that function without regard to race, color, sex, age, handicap, or national origin. For information on obtaining other extension publications, contact your county Cooperative Extension Service office. Florida Cooperative Extension Service/Institute of Food and Agricultural Sciences/University of Florida/Christine Taylor Waddill, Dean. 


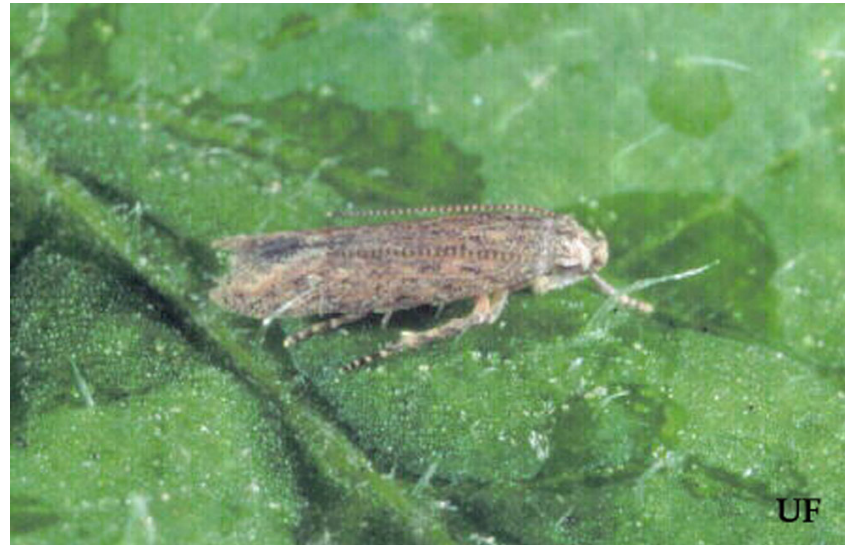

Figure 1. Adult of the tomato pinworm, Keiferia lycopersicella, (Walshingham). Credits: David J. Schuster, University of Florida

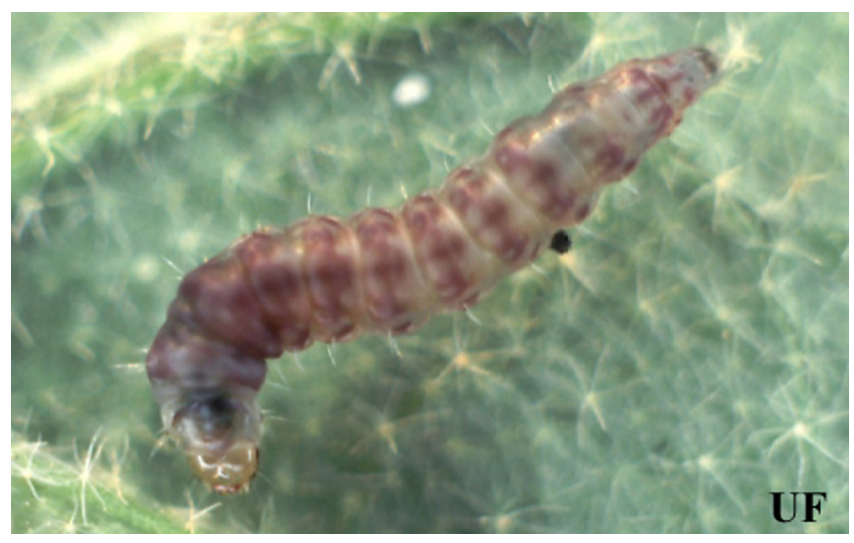

Figure 2. Larva of the tomato pinworm, Keiferia lycopersicella, (Walshingham). Credits: James Castner, University of Florida

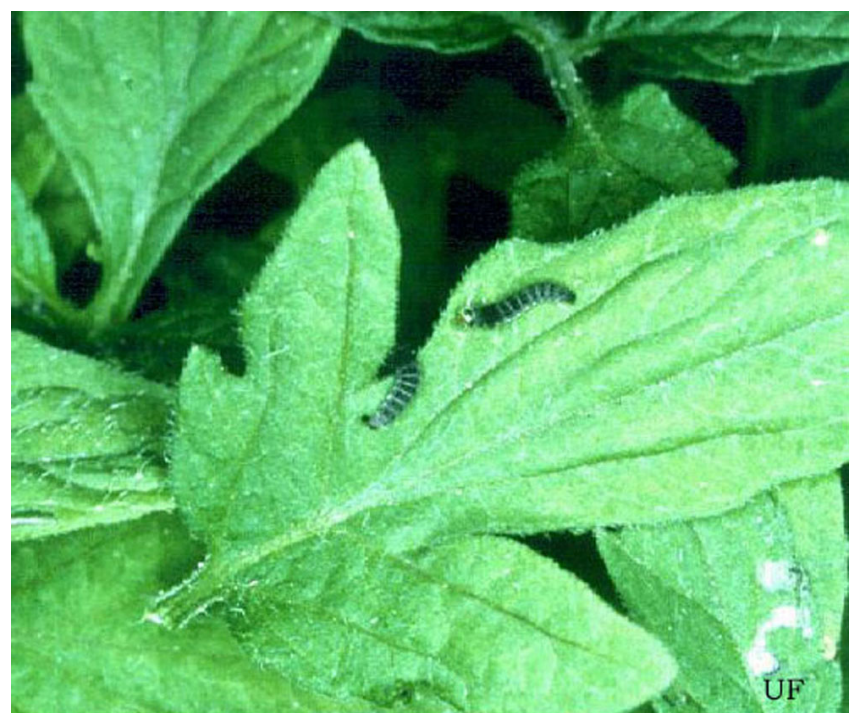

Figure 3. Larvae of the tomato pinworm, Keiferia lycopersicella, (Walshingham). Credits: University of Florida

\section{Hosts}

Plants of the nightshade family, (Solanaceae), are the preferred hosts of pinworms. Tomato, Lycopersicon esculentum L., is infested most commonly, but eggplant, Solanum melongena L. var 'esculentum' Nees, and potatoes, Solanum tuberosum L. also are attacked. Weeds such as S. carolinense L., S. xanthii Gray, and S. umbelliferum Esch. have been suitable hosts. Tomato, potato, eggplant, and a weed, S. bahamese L., are recorded hosts in Florida.

\section{Economic Importance}

Damage to tomatoes results from the feeding of larvae on leaves, stems and fruit. Initial injury is slight and appears as a small leaf mine. Later injury includes leaf folding and leaf tying. Mature larvae may abandon the leaf and bore into the fruit leaving a small "pin" size hole. Secondary damage results when plant tissues become infected by pathogens and the plant dies or the fruit rots. Approximately 60 to 80 percent of tomato fruits may become infested in a single season (Elmore and Howland 1943).

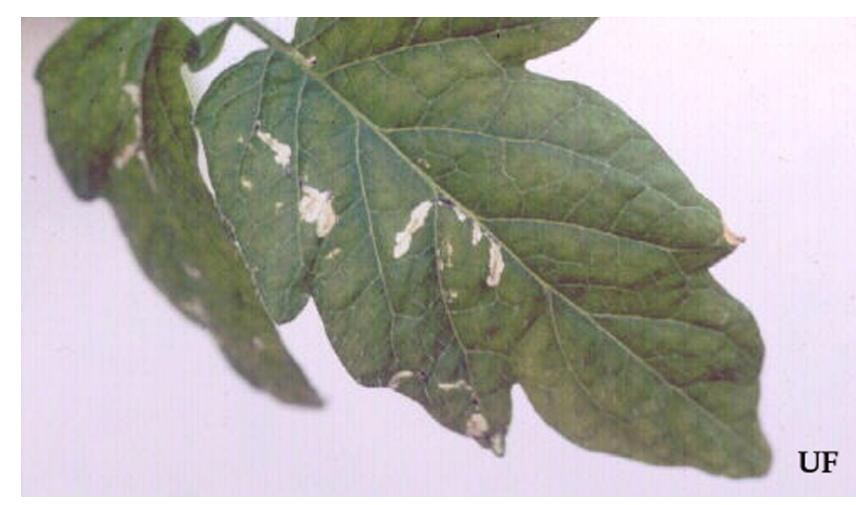

Figure 4. Leaf mining damage caused by the tomato pinworm, Keiferia lycopersicella, (Walshingham). Credits: David J. Schuster, University of Florida

\section{Management}

Several sanitary measures should be followed because infestations often result from shipment of pinworms in picking containers, crates, infested fruit or seedlings, and from populations perpetuated on plants left in fields after harvest or left in seed flats or compost heaps (Poe 1973). The precautions include use of transplants that are free of eggs and larvae 

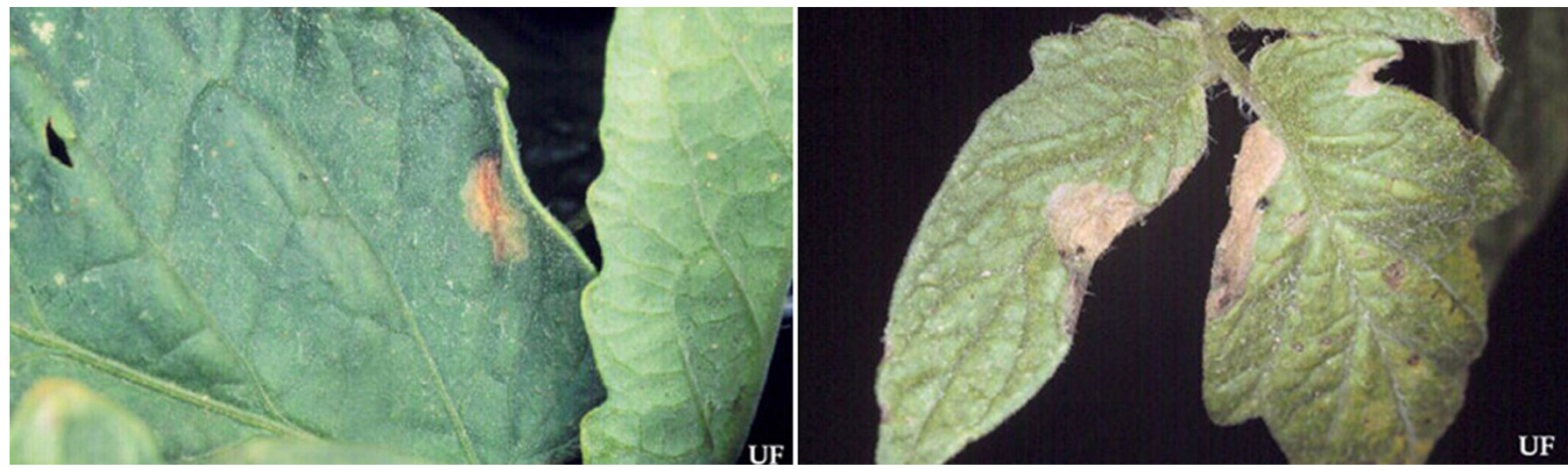

Figure 5. Leaf folding damage to tomato by the tomato pinworm, Keiferia lycopersicella, (Walshingham). Credits: David J. Schuster, University of Florida

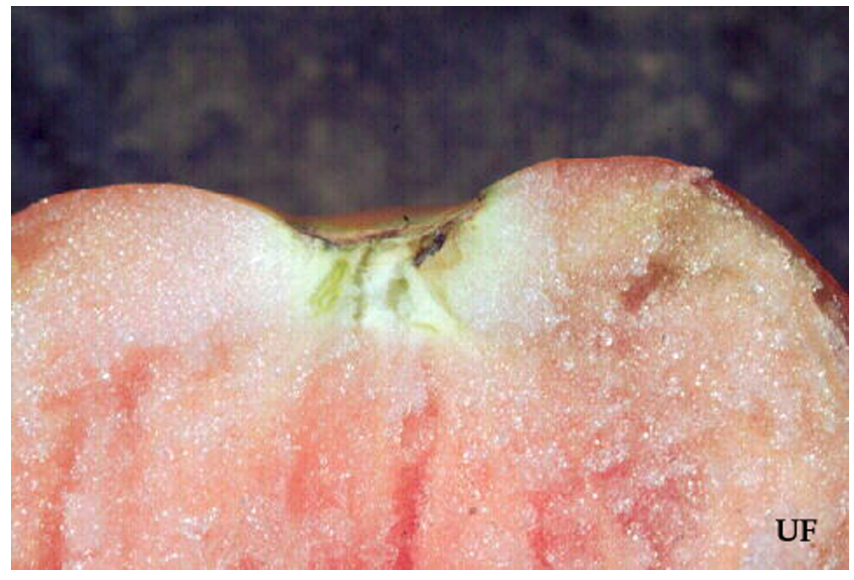

Figure 7. Tomato fruit showing damage by tomato pinworm, Keiferia lycopersicella, (Walshingham).

when set in the field, and the destruction of all plant debris and fields after harvest. Populations may be controlled early during the first or second larval stages with several recommended insecticides (Poe 1973); however, third or fourth instars are protected by leaf folds or fruit, making the control of older infestations difficult. Consequently, chemical control is contingent upon frequent and accurate observations of fields for pinworm mines.

For more information see Insect Management Guide for Tomatoes

\section{Selected References}

Busck, A. 1928. Phthorimaea lycopersicella, N. sp. (Family: Gelechiidae) a leaf feeder on tomato (Lep.). Hawaiian Ent. Soc. Proc. 7: 171-176.
Capps, H.W. 1946. Description of the larvae of Keiferia penicula Heim., with a key to the larvae of related species attacking eggplant, potato and tomato in the United States. Annals, ESA 39: 561-563.

Elmore, J.C., and A.F. Howland. 1943. Life history and control of the tomato pinworm. USDA Tech. Bull. 841. 30 p.

Poe, S.L. 1973. The tomato pinworm in Florida. UF/IFAS, AREC Research Report GC1973-2. 5 pp.

Thomas, C.A. 1933. Observations on the tomato pinworm (Gnorimoschema lycopersicella Busck) and the eggplant leafminer (G. glochinella Zeller) in Pennsylvania. J. Econ. Entomol. 26: 137-143.

Table 1. Life Cycle of Tomato Pinworm

\begin{tabular}{||l|c|c||}
\hline \hline \multirow{2}{*}{$\begin{array}{c}\text { Developmental } \\
\text { Stage }\end{array}$} & \multicolumn{2}{|c||}{ Number of Days Required } \\
\cline { 2 - 3 } & Average & Minimum \\
\hline Egg incubation & 8.9 & 4 \\
\hline Leaf mining & 11.5 & 5 \\
\hline Leaf folding & 9.5 & 3 \\
\hline Prepupae & 6.9 & 1 \\
\hline Pupa & 30.2 & 15 \\
\hline Egg to adult & 67.0 & 28 \\
\hline \hline
\end{tabular}

